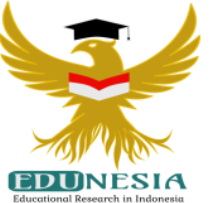

\title{
Technology Acceptance Model (TAM) in the Use of Online Learning Applications During the Covid-19 Pandemic for Parents of Elementary School Students
}

\author{
Aulia Nuraini Kusumadewi'; Nanda Anthony Lubis²; Rhomy Adhy Prastiyo3; \\ Dewi Tamara ${ }^{4}$
}

\author{
1,2,3,4Binus Business School Master Program, Bina Nusantara University, Indonesia \\ ${ }^{4}$ Corresponding Email: dtamara@binus.edu, Phone Number :0812 xxxx xxxx
}

\section{Article History:}

Received: Dec 06, 2020

Revised: Dec 20, 2020

Accepted: Dec 23, 2020

Published: Jan 01, 2021

\section{Keywords:}

TAM, Online learning, Elementary school, Covid19, Partial Least SquareStructural Equation Models.

\section{Kata Kunci:}

TAM, Online learning, Sekolah Dasar, Covid-19, Partial Least SquareStructural Equation Models.

\section{How to cite:}

Kusumadewi, A.N., Lubis, N.A., Prastiyo, R.A., \& Tamara, D. (2021). Technology Acceptance Model (TAM) in the Use of Online Learning Applications During the Covid-19 Pandemic for Parents of Elementary School Students. Edunesia: Jurnal Ilmiah Pendidikan, 2 (1): 272-292.

This is an open access article under the CC-BY-NC-ND license

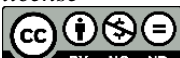

\begin{abstract}
School from Home is one of the Indonesian government's efforts to minimize the spread of the Covid-19. All teaching and learning activities have been transferred to various online learning applications, including elementary school students. The parents of these elementary school students have to operate multiple online learning applications so that their children can participate in distance learning activities. Researchers have already used the original Technology Acceptance Model (TAM) to determine the acceptance of online learning applications by parents of elementary school students as a means of distance learning. Researchers want to know the acceptance of online learning applications which are carried out in sudden conditions and without prior preparation but must be implemented. Researchers hope that the results of this study can capture the acceptance of parents of elementary students to School from Home during the Pandemic and can be used for evaluation and continuous improvement of the School from Home system. Referring to the literature with 22 questionnaire questions, the minimum number of respondents who must be obtained is 110 people, in this study 155 parents of elementary school students in Jabodetabek participated in filling out the questionnaire using an online questionnaire with a significance level of 5\% and data processed using PLS-SEM 3.0 resulted in a strong relationship. There is no significant difference between Perceived Ease of Use and Attitude Toward Using. Then, a significant relationship was generated between Perceived Ease of Use on Perceived Usefulness, Perceived Usefulness on Attitude Toward Using, Perceived Usefulness on Behavioral Intention To Use, Attitude Toward Using on Behavioral Intention To Use. However, the results show a positive value Path Coefficient in Structural Model Result, so this research is consistent and according to TAM.
\end{abstract}

Abstrak: School from Home menjadi salah satu upaya pemerintah Indonesia dalam mengurangi penyebaran virus Covid-19. Seluruh kegiatan belajar mengajar dialihkan dengan menggunakan berbagai aplikasi online learning, begitu pula dengan pendidikan untuk murid Sekolah Dasar. Para orang tua murid Sekolah Dasar ini, bagaimanapun juga harus mendampingi dan mengoperasikan berbagai aplikasi online learning agar putra putrinya dapat mengikuti kegiatan pembelajaran jarak jauh. Peneliti menggunakan Technology Acceptance Model (TAM) asli untuk mengetahui penerimaan aplikasi online learning oleh orang tua murid Sekolah Dasar ini sebagai sarana pembelajaran jarak jauh. Peneliti ingin mengetahui penerimaan aplikasi online learning yang dilaksanakan dalam kondisi mendadak dan tanpa persiapan sebelumnya namun harus dilaksanakan. Peneliti berharap hasil penelitian ini dapat menangkap penerimaan orang tua murid siswa SD terhadap School from Home selama Pandemi dan dapat digunakan untuk evaluasi maupun perbaikan berkelanjutan sistem School from Home. Mengacu pada literatur dengan 22 pertanyaan kuesioner, minimum responden yang harus didapatkan sebanyak 110 orang, dalam penelitian ini 155 orang tua murid SD di Jabodetabek berpartisipasi dalam pengisian kuesioner menggunakan online kuesioner dan tingkat signifikansi 5\% dan data diolah menggunakan PLS-SEM 3.0 menghasilkan hubungan yang tidak signifikan antara Perceived Ease of Use terhadap Attitude Toward Using. Kemudian, dihasilkan hubungan yang signifikan antara Perceived Ease of Use terhadap Perceived Usefulness, Perceived Usefulness terhadap Attitude Toward Using, Perceived Usefulness terhadap Behavioral Intention To Use, Attitude Toward Using terhadap Behavioral Intention To Use. Namun, Hasil dari model penelitian ini tetap dikatakan konsisten dan sesuai dengan TAM, karena nilai Path Coefficient pada Structural Model Result yang dihasilkan seluruhnya bernilai positif. 


\section{A. Introduction}

In the conditions of the Covid-19 pandemic, where it cannot be predicted when it will end, technology is essential for communication. During limiting social activities and physical distancing, the world depended on technology for activities such as research and work. The utilization of information and communication technology, especially in education, continues to increase. This online learning for students is a follow-up to the Circular of the Minister of Education and Culture dated 17 March 2020 to prevent the spread of Covid-19 in Indonesia. This condition also urges distance education that has never been implemented simultaneously before and requires the involvement of all elements of education, including students, teachers and parents (Sun et al., 2020). The distance education process requires appropriate learning media so that it can maximize the learning process, one form of information and communication technology that can optimizing the distance learning process is through online learning application media. Distance learning (online learning) is an education process or activity by technology such as computers, smartphones, the internet, applications, and tools. The online learning provides students with a virtual atmosphere in which students take part in several activities (Al-Rahmi et al., 2018). Learning through online learning applications can be a success in primary education and depends on the parents of students' involvement. Acceptance and parents' ability to adapt and get used to using technology is a necessity and necessity to assist the learning process with the use of technology (Hollingworth et al., 2011).

With the continued development of online learning application technologies such as Adobe Connect, Skype, Zoom, Google Classroom, Google Meet and others, where it is possible to used anywhere and anytime on a mobile phone or computer device (Barbosa \& Barbosa, 2019), acceptance for parents of students that technology can provide convenience and benefits in learning activities will be the key to success. acceptance for parents of students that technology can provide convenience and benefits in learning activities will be the key to success. Following the development of external factors that affect TAM, a research conduct by (Salloum et al., 2019) to determine the acceptance of e learning. The research found that the role of computer playfulness provides a significant effect to perceived ease of use in e learning besides quality systems and computer self-efficacy. Then information quality together with perceived enjoyment and accessibility has a significant effect on both perceived ease of use and perceived usefulness. According to (Hussein, 2017) in his research stated that along with technological advances, the demand for the application of e learning in universities increases, but it is not in line with the intensity of its use. It is found that attitude is the most important role in influencing students' intention to contribute to e learning. However, other research shows that there are still obstacles to applying to learn with online learning application technology. Problems come when many students are not motivated and do not want to actively interact in learning through online learning applications even though they have encouraged them to interact. This happens because of a lack of motivation, interest, and personal character (Candarli \& Yuksel, 2012).

This research will be focused on exploring the acceptance of online learning application technology with the scope of Elementary School (SD) students throughout Jabodetabek. However, the targeted respondents are parents who accompany their children in school from home (SFH) activities. Based on data from the Ministry of Education and Culture (2020), the number of SD students in the even semester of the 2019/2020 school year in Jabodetabek is $2,775,549$. Concerning the participation of parents in applying technology to the learning process for their children, research by (Powell \& Wimmer, 2017) shows that 
Perceived Usefulness and Perceived Ease of Use will influence the possibility of parents recommending technology as the main thing for children. The results reveal that parents' perceptions of Perceived Usefulness affect their willingness to recommend technology as a learning medium for their children. On the other hand, parents pay less attention to aspects of the easyness in using technology.

The purpose of this research is to analyze further how the parents of elementary school students in the Jabodetabek area acceptance on the use of online learning applications through the original TAM model, which has been widely apply in various research related to the technology acceptance used in educational environments (Oye, Lahad, and Rahim 2012). The focus of the research relies on parents as companions of elementary school students who, during the Covid-19 pandemic, must assist their children in the learning process through online learning applications.

\section{Literature Review}

Technology Acceptance Model (TAM)

TAM is a theoretical model invented by (Davis et al., 1989). This model is a development of the Theory of Reasoned Action (TRA) theory, a theoretical model widely used in social psychology studies (Fishbein \& Azjen, 1975). TAM is a theoretical model specifically used to determine user behavior towards the use of information/technology systems. Furthermore, TAM describes the causal relationship between two main factors, namely Perceived Usefulness and Perceived Ease of Use with Behavioral Intention To Use and usage behavior in technology use, where Usage Behavior is affected by Behavioral Intention To Use which has a mediating relationship between Perceived Usefulness and Perceived Ease of Use with Usage Behavior (Davis et al., 1989; Lanlan et al., 2019).

TAM has been used extensively in various kinds of research related to technology use and user behavior. Some examples of research and studies that have implemented TAM to determine user acceptance of the use or adoption of various technologies are internet banking technology (Al-Smadi, 2012), electronic learning on mobile (Tan et al., 2012), social media (Rodrigues Pinho \& Soares, 2011), online shopping/e-commerce (Vijayasarathy, 2004).

\section{Perceived Ease of Use}

Perceived Ease of Use is a measurement used to determine the perceptions of individual to the technology considering the easyness of its usage (Davis et al., 1989). Referring to (Wang B. \& Ha-Brookshire J.E., 2019), Perceived Ease of Use relates to the extent to which users believe that technology is easy to use and without constraints. Many previous studies show that Perceived Ease of Use positively impacts user acceptance of technology and user behavior (Lanlan et al., 2019).

Research conducted by (Wang B. \& Ha-Brookshire J.E., 2019) on textile industry sector companies in China that have implemented new technology shows that the Perceived Ease of Use emphasizes several aspects, namely no need / need a little training in the use of new technology, ease of adoption of new technologies on the company, and the ease in using a new technology. Research (Ozturk et al., 2016) conducted in the hotel industry said that Perceived Ease of Use had a significant impact on increasing user behavioral intentions to use mobile hotel booking services. Perceived Ease of Use also has a positive impact on user loyalty and comfort. 


\section{Perceived Usefulness}

Perceived Usefulness is a measurement used to determine individual perceptions that technology can improve individual performance at work (Davis et al., 1989). It relates to individual perceptions that technology will increase individual efficiency at work (Davis et al., 1989). If individual performance at work has increased, it means that there is a positive influence in using technology, and individual behavior will also change positively (Lanlan et al., 2019). In formulating hypotheses, (Park et al., 2014) found that Perceived Usefulness has a direct positive effect on Behavioral Intention To Use in technology usage.

Based on previous research (Kapoor et al., 2014), TAM's use of RFID (RadioFrequency Identification) technology in library management shows that Perceived Usefulness and system quality have a positive effect on user behavior. In contrast, User behavior and system quality will significantly affect the use of RFID services. Other research shows that Perceived Usefulness has a positive impact on Behavioral Intention To Use in the technology usage, as has been done by (Abbas \& Hamdy, 2015) with the use of mobile communication service provider technology and the use of online travel service technology (Li \& Liu, 2014).

\section{Attitude Towards Using}

Attitude Toward Using is the behavior of users influenced by the strongest belief in online learning applications (Davis et al., 1989). In this research, Attitude Toward Using has a mediating relationship between Perceived Ease of Use and Perceived Usefulness on Behavioral Intention To Use. Previous research (Masrom, 2007; Weng et al., 2018) also uses Attitude Toward Using mediation, which connects Perceived Ease of Use and Perceived Usefulness to Behavioral Intention To Use.

\section{Behavioral Intention To Use}

Behavioral Intention To Use can be defined as the tendency of the user's intention to use new technology (Loanata \& Tileng, 2016). Meanwhile, according to (Handoko, 2019), Behavioral Intention To Use is defined as the assumption of supporting factors that influence behavior. This assumption can be measured by how much the individual wants to buy supporting equipment in using technology (Loanata \& Tileng, 2016). Behavioral Intention To Use can also be associated with individual feelings, both positive and negative in relation to the intention to carry out activities.

\section{B. Method}

Research in the world of education using original TAM and its development has been done a lot. (Masrom, 2007) conducted research for the first time related to e-learning acceptance using TAM for higher education and then followed several other studies considering e-learning acceptance.

Research by (Masrom, 2007) also explains that his research supports the Original TAM. Except for Attitude Toward Using, it does not have a significant effect on Behavioral Intention To Use. (Farahat, 2012) states that Perceived Ease of Use has a significant relationship with Perceived Usefulness, both of which are significant for Attitude Toward Using. Alternatively, in other words, TAM's research (Farahat, 2012) on e-learning acceptance for Egyptian students is in line with the Original TAM.

TAM with variable development (Tarhini et al., 2013) and (Ibrahim et al., 2018) have different original TAM results. (Tarhini et al., 2013) stated that his research on Web-based 
Learning Systems acceptance in European Higher Education with several additional variables related to Social, Organizational and Individual factors resulted in Perceived Ease of Use and Perceived Usefulness, which had a significant influence on Behavioral Intention. Meanwhile (Ibrahim et al., 2018), through his research on 95 undergraduate students at Tuanku Abdul Rahman University College (TARUC), it was found that Perceived Ease of Use did not have a significant effect. And then Perceived Usefulness and Perceived Usefulness di not have a significant effect on Behavioral Intention to Use. However, the Perceived Ease of Use has a significant effect on Behavioral Intention. The research also added some other factors such as Social Norms, Quality of work-life, Self-efficacy, and Facilitating Conditions variables.

Apart from being carried out at the higher education level, other research has been conducted (Robinson, 2019) regarding the online learning acceptance with TAM for nontraditional students in America. His research stated consistency with the original TAM, although Perceived Ease of Use did not significantly affect Attitude Toward Using.

Previous research for TAM in education related to e-learning was mostly carried out at the higher education level, making students direct online learning applications as research samples. However, in this research, the end-users of the online learning application are still children, so they need assistance. So, different from previous studies, the researcher conducted a research by applying TAM to determine the acceptance of online learning applications for elementary school students' parents as mentors. A person who is not a direct beneficiary, but a user who directly operates an online learning application for their children during SFH activities during the Covid-19 Pandemic.

Apart from the research object, another difference between this research and previous research is the situation and condition of the sample/object of research in using an information system. In general, the condition of acceptance of information systems is carried out slowly and gradually. However, this research was conducted in a condition that the acceptance of online learning applications for elementary school-aged students was quite sudden and without preparation, considering it was a form of reactive efforts to the Covid19 pandemic.

Using the original TAM, this research identified the relationship between Perceived Ease of Use, Perceived Usefulness, Attitude Toward Using, and Behavioral Intention To Use on acceptance of online learning applications. According to the two differences of conditions and variations in the differences in results from previous research, the hypothesis we propose:

H1: Perceived Ease of Use has a significant effect on Attitude Toward Using.

H2: Perceived Ease of Use has a significant effect on Perceived Usefulness.

H3: Perceived Usefulness has a significant effect on Attitude Toward Using.

H4: Perceived Usefulness has a significant effect on Behavioral Intention To Use.

H5: Attitude Toward Using has a significant effect on Behavioral Intention To Use.

This research uses the TAM theory with the following research model: 


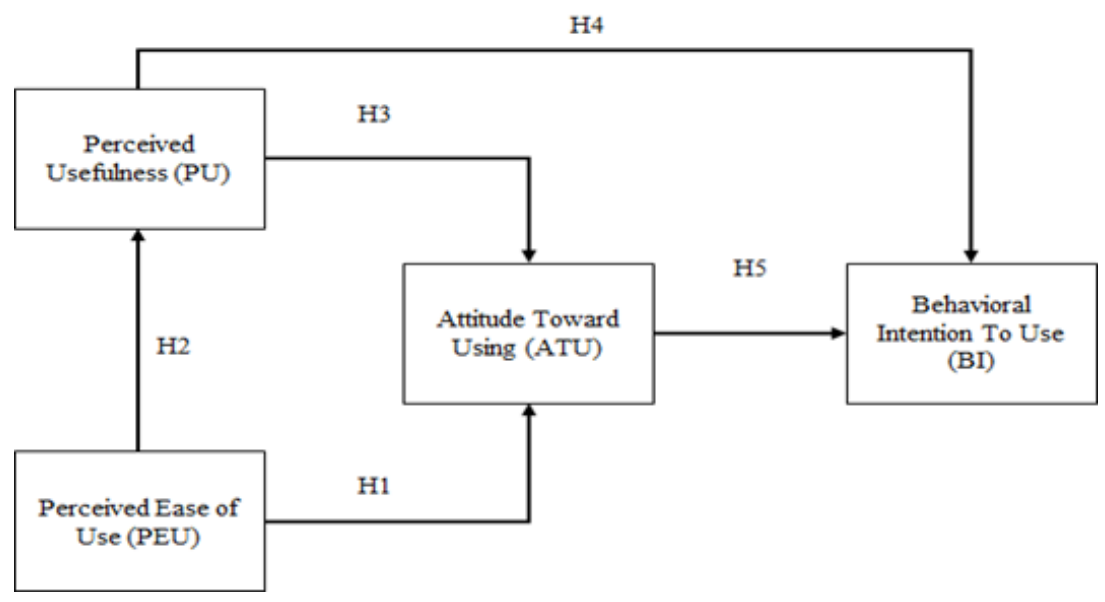

Figure 1. Research Model

\section{Sample Description}

Our research strategy is to distribute questionnaires to collect primary data regarding respondents' perceptions and behavior towards the acceptance of online learning application technology. This research is exploratory and descriptive, which focuses on the behavior of the respondents. This research was conducted in a natural environment with minimal interference from the researchers. Research carried out in a natural environment that is exploratory and descriptive in nature can be called a non-contrived field research where the researcher wants to explore more about the causal relationship between the variables used in this research. An individual becomes the unit of analysis of this research, namely parents who have children who are currently attending elementary school. The time horizon related to data collection in this research was carried out only once and took a maximum of 3 months (Sekaran \& Bougie, 2016).

The target population of this research is parents whose children are currently attending elementary school in Jabodetabek. As a sample, we assume one parent accompanies one child in their daily online learning through online learning applications. So that from the data on the number of elementary school students in Jabodetabek, the population is 2,775,549 parents as mentors. Sampling as respondents in this study was determined using the purposive sampling method where the research was carried out in a specific area so that several criteria had been determined by the researcher, such as the respondents were parents who have children who are currently studying at elementary schools in the Greater Jakarta area. These parents are currently is accompanying their child in SFH activities online due to the Covid-19 pandemic. The Jabodetabek area was chosen because the readiness of infrastructure and human resources is the best compared to other areas, for example, the availability of internet networks, telecommunications provider signals, and the condition of schools that are more ready to run SFH. Also, because the researcher is domiciled in the Jabodetabek area, it is easy for researchers to distribute surveys to respondents.

Referring to (Joseph F Hair et al., 2019), determining the minimum number of respondents is determined from the number of questionnaire questions of 22 with a ratio of 1: 5 so that the minimum number of respondents is $22 \times 5=11$. From the results of the questionnaire data analysis, we were using data from 155 respondents. Data collection in this research was conducted using a questionnaire distributed online via Google Form. The 
link of the questionnaire was distributed to respondents via e-mail and messenger applications on smartphones. The questionnaire list is ordinal data using a Likert scale from 1 to 5 , where scale 1 strongly disagrees, scale 2 disagrees, scale 3 is neutral, scale 4 agrees, and scale 5 very agree. The question items in the questionnaire which is used to measure all variables were adapted from (Suh \& Han, 2002).

Data Analysis Technique

Analyzing the data collected statistically applies the Partial Least Square-Structural Equation Modeling (PLS-SEM) method using SmartPLS 3.0. In assessing and reporting on the PLS-SEM data output following (Hair, J. F., Hult, G. T. M., Ringle, C. M., \& Sarstedt, 2013) recommendations where there are two stages of evaluation. The first stage is the evaluation of measurement models to evaluate the validity and reliability of the constructs and indicators, then the second stage structural model evaluation to test hypotheses and the relationship between latent variables.

\section{Operationalization of Variables}

In accordance with the data analysis method in this research, which uses PLS-SEM, then based on (Joseph F Hair et al., 2019; Santoso, 2004), the variables used in this research include:

- Exogenous variables or independent variables are variables that can stand alone and cannot be predicted by other variables. The independent variables in this research are Perceived Usefulness and Perceived Ease of Use.

- An endogenous variable or dependent variable is a variable that cannot stand alone and is predicted or explained by the independent variable. The dependent variable in this research is the Attitude Toward Using and Behavioral Intention To Use.

- Measurable variables (indicators) are indicators used to measure the independent variable and the dependent variable. Table 1 shows the indicators of this research.

Table 1. Constructs and Indicator

\begin{tabular}{|c|c|c|c|c|}
\hline No & Constructs & Code & Measurement Indicators & Reference \\
\hline \multirow[t]{4}{*}{1} & \multirow[t]{4}{*}{$\begin{array}{l}\text { Perceived } \\
\text { Ease of Use }\end{array}$} & PEU1 & $\begin{array}{l}\text { It was easy for me to learn how to use the } \\
\text { online learning application for my } \\
\text { son/daughter's School From Home } \\
\text { (SFH) activities }\end{array}$ & \multirow[t]{4}{*}{$\begin{array}{c}\text { (Suh and } \\
\text { Han, 2002) }\end{array}$} \\
\hline & & PEU2 & $\begin{array}{l}\text { The online learning application makes it } \\
\text { easy to realize what I want in my } \\
\text { son/ daughter's School From Home } \\
\text { (SFH) activities }\end{array}$ & \\
\hline & & PEU3 & $\begin{array}{l}\text { It's easy for me to remember how to use } \\
\text { the online learning application for my } \\
\text { son/daughter's School From Home } \\
\text { (SFH) activities }\end{array}$ & \\
\hline & & PEU4 & $\begin{array}{l}\text { I find that the online learning application } \\
\text { is easy for me to use for my son / } \\
\text { daughter's School From Home (SFH) } \\
\text { activities }\end{array}$ & \\
\hline
\end{tabular}




\begin{tabular}{|c|c|c|c|c|}
\hline No & Constructs & Code & Measurement Indicators & Reference \\
\hline \multirow[t]{4}{*}{2} & \multirow[t]{4}{*}{$\begin{array}{l}\text { Perceived } \\
\text { Usefulness }\end{array}$} & PU1 & $\begin{array}{l}\text { Using this online learning application } \\
\text { enhances my productivity (as a parent) }\end{array}$ & \multirow[t]{4}{*}{$\begin{array}{c}\text { Suh and } \\
\text { Han, 2002) }\end{array}$} \\
\hline & & PU2 & $\begin{array}{l}\text { The use of online learning applications } \\
\text { has a critical role in supporting my son / } \\
\text { daughter's School From Home activities }\end{array}$ & \\
\hline & & PU3 & $\begin{array}{l}\text { Using online learning applications } \\
\text { makes my son / daughter's School From } \\
\text { Home activities easier }\end{array}$ & \\
\hline & & PU4 & $\begin{array}{l}\text { I find Online learning application is } \\
\text { useful for my son / daughter's School } \\
\text { From Home activities }\end{array}$ & \\
\hline \multirow[t]{5}{*}{3} & \multirow[t]{5}{*}{$\begin{array}{l}\text { Attitude } \\
\text { Toward } \\
\text { Using }\end{array}$} & ATU1 & $\begin{array}{l}\text { Using online learning applications for } \\
\text { School From Home during the Covid- } 19 \\
\text { Pandemic is a good idea }\end{array}$ & \multirow[t]{5}{*}{$\begin{array}{c}\text { (Suh and } \\
\text { Han, 2002) }\end{array}$} \\
\hline & & ATU2 & $\begin{array}{l}\text { Using online learning applications for } \\
\text { School From Home during the Covid-19 } \\
\text { Pandemic is a wise idea }\end{array}$ & \\
\hline & & ATU3 & $\begin{array}{l}\text { Using the online learning application for } \\
\text { School From Home during the Covid-19 } \\
\text { Pandemic is a fun idea }\end{array}$ & \\
\hline & & ATU4 & $\begin{array}{l}\text { Using online learning applications for } \\
\text { School From Home during the Covid-19 } \\
\text { Pandemic is a positive idea }\end{array}$ & \\
\hline & & ATU5 & $\begin{array}{l}\text { The advantages of using online learning } \\
\text { applications outweigh the disadvantages }\end{array}$ & \\
\hline \multirow[t]{4}{*}{4} & \multirow[t]{4}{*}{$\begin{array}{l}\text { Behavioral } \\
\text { Intention } \\
\text { To Use }\end{array}$} & BI1 & $\begin{array}{l}\text { I intend to continue using the online } \\
\text { learning application to support my son / } \\
\text { daughter's School From Home activities }\end{array}$ & \multirow[t]{4}{*}{$\begin{array}{l}\text { (Suh and } \\
\text { Han, 2002) }\end{array}$} \\
\hline & & $\mathrm{BI} 2$ & $\begin{array}{l}\text { I hope that the use of online learning } \\
\text { applications for my son / daughter's } \\
\text { School From Home activities will } \\
\text { continue in the future }\end{array}$ & \\
\hline & & BI3 & $\begin{array}{l}\text { I will often use the online learning } \\
\text { application for my son / daughter's } \\
\text { School From Home activities in the } \\
\text { future }\end{array}$ & \\
\hline & & BI4 & $\begin{array}{l}\text { I will recommend the online learning } \\
\text { application for my son / daughter's } \\
\text { School From Home activities to others }\end{array}$ & \\
\hline
\end{tabular}

\section{Research Instrument}

Referring to (Santoso, 2012), this research instrument is a survey that has been distributed online to respondents. To complete this survey, respondents were asked to answer general questions (demographic questions) which would be used as a basis for whether the respondent met the criteria set by the researcher. Then the respondents were 
asked to answer their perceived perceptions by selecting the Likert scale indicator 1-5, where the answer to Strongly Disagree is 1, Disagree is worth 2, Neutral is worth 3, Agree is worth 4, and Strongly Agree is worth 5.

\section{Result and Discussion}

\section{Demographic Information}

The following is a demographic mapping of the respondents of this research, which contains the profiles of parents who accompany their sons or daughters to conduct distance learning by operating online learning applications. It shown that the sample is dominated by women at $72.9 \%$. The age of the respondents was dominated by parents with range of 3140 with a percentage of $69 \%$. For the education level of the most respondents is a Bachelor (S1/D4) with a percentage of $58.1 \%$. Meanwhile, the most domicile profiles were from the Tangerang Raya area, with a percentage of $36.1 \%$. Table 2 shows the Complete demographic data.

Table 2. Respondent Demography

\begin{tabular}{|c|c|c|c|}
\hline Demographic & Identification & Frequency & Percentage $(\%)$ \\
\hline \multirow{3}{*}{ Gender } & Male & 42 & 27.1 \\
\hline & Female & 113 & 72.9 \\
\hline & Total & 155 & 100 \\
\hline \multirow{6}{*}{ Age } & $<20$ Years & 1 & .6 \\
\hline & $20-30$ Years & 2 & 1.3 \\
\hline & 31 - 40 Years & 107 & 69.0 \\
\hline & 41 - 50 Years & 43 & 27.7 \\
\hline & $>50$ Years & 2 & 1.3 \\
\hline & Total & 155 & 100 \\
\hline \multirow{7}{*}{ Education } & $\begin{array}{l}\text { Elementary school graduate / } \\
\text { equivalent }\end{array}$ & 2 & 1.3 \\
\hline & $\begin{array}{l}\text { Junior high school graduate / } \\
\text { equivalent }\end{array}$ & 3 & 1.9 \\
\hline & High school graduate / equivalent & 23 & 14.8 \\
\hline & Diploma (D1-D3) & 23 & 14.8 \\
\hline & Bachelor (S1/D4) & 90 & 58.1 \\
\hline & Masters (S2) & 14 & 9.0 \\
\hline & Total & 155 & 100 \\
\hline \multirow{6}{*}{ Domicile } & $\begin{array}{l}\text { Jakarta (Central, North, East, South, } \\
\text { West) }\end{array}$ & 35 & 22.6 \\
\hline & Bogor City & 18 & 11.6 \\
\hline & Depok & 27 & 17.4 \\
\hline & Tangerang City, South Tangerang Citj & 56 & 36.1 \\
\hline & Bekasi City & 19 & 12.3 \\
\hline & Total & 155 & 100 \\
\hline
\end{tabular}




\section{Measurement Model/Validity and Reliability Test}

Evaluation of Measurement models with reflective indicators is assessed through validity testing which includes convergent validity, discriminant validity, and reliability testing by evaluating composite reliability and Cronbach's alpha. In evaluating the convergent validity, the researcher first tested the outer loadings of each indicator with the minimum recommended value of at least .70 (Hair, J. F., Hult, G. T. M., Ringle, C. M., \& Sarstedt, 2013).

The next stage reseachers looking at the Average Variance Extracted (AVE) value of all the constructs in the research model with the minimum AVE value recommended by AVE> .50 (Fornell \& Larcker, 1981), AVE will show how far the construct integrates with its indicators and is able to explain variance. of each indicator item, the minimum AVE value of .50 indicates that on average the construct can explain $50 \%$ of the variances of the indicator item (J. F. Hair et al., 2017).

In discriminant validity, evaluation is carried out by looking at the square root of the Average Variance Extracted (AVE), the correlation between the latent variables and the Heterotrait-Monotrait Ratio (HTMT) and Cross loadings. The square root value of each construct must be greater than the correlation of one construct with other constructs in the research model (Fornell and Larcker, 1981). Then for cross loading the required value, namely the loading value of the indicator on the latent variable set must be greater than the loading of other latent variables. In discriminant validity, HTMT between two constructs can be determined if HTMT .85 has a value below .85 when the constructs in the research model conceptually have differences or HTMT .90 has a value below .90 when the constructs in the research model are not significantly different conceptual understanding (J. F. Hair et al., 2017).

The data output from PLS-SEM as shown in Table 3 shows that all outer loadings values on all indicators are above the minimum required value of .70 and the AVE value of the construct is also above .5. In testing the reliability of the composite reliability value for all constructs used in this research, it is recommended to meet the minimum requirements of .70 (Nunnally, 1978), as well as the value of Cronbach's alpha on constructs that is used showing a value above the minimum recommendation of .70 (Cronbach, 1951). (Hair, Hult, Ringle, 2013) also recommends that the minimum outer loading value is .7. The value of Outer loading exceeds .70 mean that the construct can explain more than $50 \%$ of the variance indicator and show the reliability of the indicator.

Table 3. PLS-SEM assessment results of reflective measurement models

\begin{tabular}{lccccc}
\hline \multirow{2}{*}{$\begin{array}{c}\text { Latent } \\
\text { Variables }\end{array}$} & Indicators & \multicolumn{2}{c}{ Convergent Validity } & \multicolumn{2}{c}{$\begin{array}{c}\text { Internal Consistency } \\
\text { Reliability }\end{array}$} \\
\cline { 3 - 6 } & & Loadings & AVE & $\begin{array}{c}\text { Composite } \\
\text { Reliability }\end{array}$ & $\begin{array}{c}\text { Cronbach's } \\
\text { alpha }\end{array}$ \\
\cline { 3 - 6 } & & $>.70$ & $>.50$ & $>.70$ & $>.70$ \\
\hline \multirow{2}{*}{$\begin{array}{l}\text { Perceived Ease } \\
\text { of Use }\end{array}$} & PEU1 & .897 & & & \\
& PEU2 & .835 & .79 & .940 & .915 \\
& PEU3 & .925 & .798 & & \\
\hline
\end{tabular}




\begin{tabular}{|c|c|c|c|c|c|}
\hline \multirow{3}{*}{$\begin{array}{c}\text { Latent } \\
\text { Variables }\end{array}$} & \multirow{3}{*}{ Indicators } & \multicolumn{2}{|c|}{ Convergent Validity } & \multicolumn{2}{|c|}{$\begin{array}{c}\text { Internal Consistency } \\
\text { Reliability }\end{array}$} \\
\hline & & Loadings & AVE & $\begin{array}{l}\text { Composite } \\
\text { Reliability }\end{array}$ & $\begin{array}{c}\text { Cronbach's } \\
\text { alpha }\end{array}$ \\
\hline & & $>.70$ & $>.50$ & $>.70$ & $>.70$ \\
\hline \multirow{4}{*}{$\begin{array}{l}\text { Perceived } \\
\text { Usefulness }\end{array}$} & PU1 & .753 & \multirow{4}{*}{.769} & \multirow{4}{*}{.930} & \multirow{4}{*}{.898} \\
\hline & PU2 & .921 & & & \\
\hline & PU3 & .906 & & & \\
\hline & PU4 & .917 & & & \\
\hline \multirow{5}{*}{$\begin{array}{l}\text { Attitude } \\
\text { Toward Using }\end{array}$} & ATU1 & .884 & \multirow{5}{*}{.762} & \multirow{5}{*}{.941} & \multirow{5}{*}{.921} \\
\hline & ATU2 & .931 & & & \\
\hline & ATU3 & .814 & & & \\
\hline & ATU4 & .921 & & & \\
\hline & ATU5 & .807 & & & \\
\hline \multirow{4}{*}{$\begin{array}{l}\text { Behavioral } \\
\text { Intention to Use }\end{array}$} & BI1 & .886 & \multirow{4}{*}{.844} & \multirow{4}{*}{.930} & \multirow{4}{*}{.898} \\
\hline & BI2 & .932 & & & \\
\hline & BI3 & .944 & & & \\
\hline & BI4 & .912 & & & \\
\hline
\end{tabular}

According to the results of the PLS-SEM data output as contained in Tables 3 and 4. It is shown that all the indicators and constructs used in this research model meet the validity requirements, both convergent validity and discriminant validity, and meet the reliability requirements based on the composite reliability and Cronbach's alpha values. Meanwhile, Table 2 shows respondents' demographics who responded to the indicator items in the research questionnaire. In addition to supporting the assessment of the indicators and constructs in this research, the data output from PLS-SEM is as shown in Table 4, with the Fornell-Lacker criterion showing that the square root value of AVE that is owned in the correlation of a construct to the construct itself exceeds value held in correlation with other constructs. The HTMT criteria also show a value below .90 as recommended by (J. F. Hair et al., 2017).

Table 4. Discriminant Validity

\begin{tabular}{|c|c|c|c|c|c|c|c|c|c|}
\hline & \multicolumn{4}{|c|}{ Fornell-Larcker Criterion } & \multicolumn{5}{|c|}{ Heterotrait-Monotrait Ratio (HTMT) } \\
\hline & ATU & BI & PEU & PU & & ATU & BI & PEU & PU \\
\hline ATU & .873 & & & & ATU & & & & \\
\hline BI & .767 & .919 & & & BI & .815 & & & \\
\hline PEU & .679 & .713 & .893 & & PEU & .735 & .765 & & \\
\hline PU & .792 & .720 & .760 & .877 & PU & .867 & .780 & .837 & \\
\hline
\end{tabular}




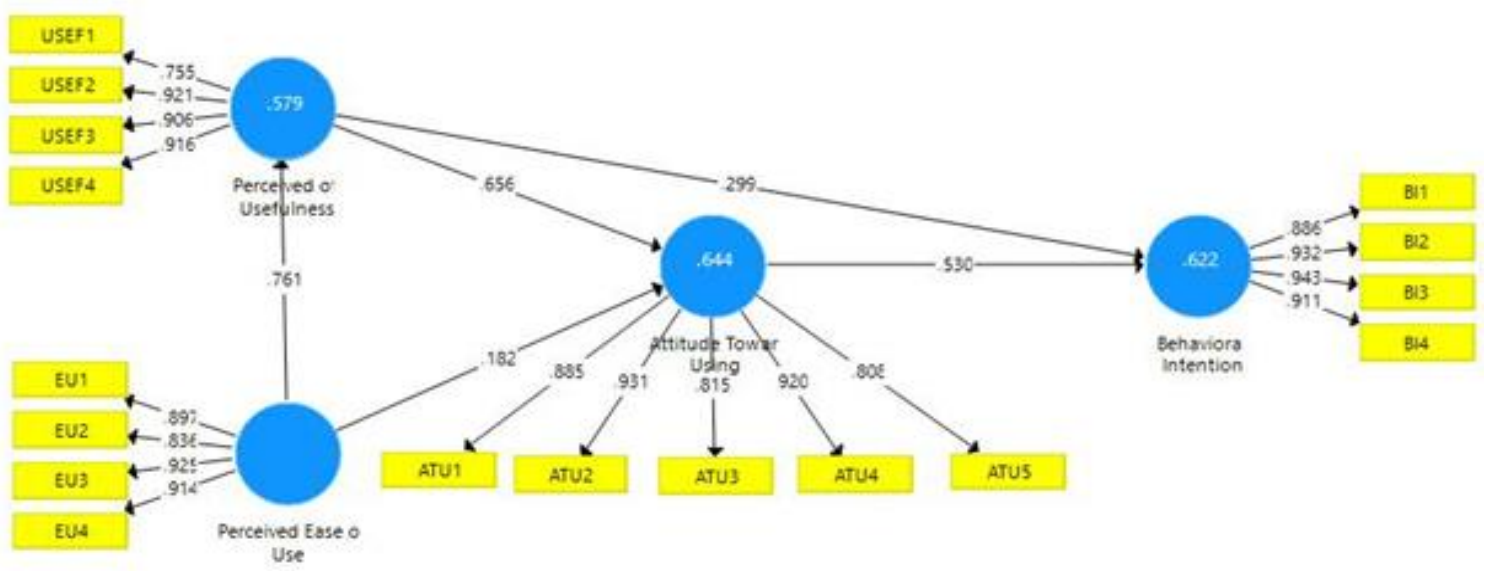

Figure 2. Research Model in PLS-SEM

\section{Structural Model}

The PLS-SEM data output for the Structural Model is presented in table 5. A structural model evaluation is carried out to see if there is a relation and influence on the research variables and their path coefficients. Besides, it will also be seen how much the significance of the relationship on the research variables that were built. To process this, a bootstrapping was carried out using 5,000 subsamples as recommended by (Chinn, 1998).

Table 5. Structural Model Result

\begin{tabular}{lcccc}
\hline \multicolumn{1}{c}{ Relationship } & $\begin{array}{c}\text { Path } \\
\text { Coefficient }\end{array}$ & $\boldsymbol{t}$-Values & $\boldsymbol{p}$-Values & Sig. Level \\
\hline $\begin{array}{l}\text { Attitude Toward Using } \rightarrow \\
\text { Behavioral Intention }\end{array}$ & .529 & 6.006 & .000 & Significance \\
\hline $\begin{array}{l}\text { Perceived Ease of Use } \rightarrow \text { Attitude } \\
\text { Toward Using }\end{array}$ & .183 & 1.677 & .094 & $\begin{array}{c}\text { Not } \\
\text { Significance }\end{array}$ \\
\hline $\begin{array}{l}\text { Perceived Ease of Use } \rightarrow \text { Perceived } \\
\text { Usefulness }\end{array}$ & .760 & 16.444 & .000 & Significance \\
\hline $\begin{array}{l}\text { Perceived Usefulness } \rightarrow \text { Attitude } \\
\text { Toward Using }\end{array}$ & .653 & 7.519 & .000 & Significance \\
\hline $\begin{array}{l}\text { Perceived Usefulness } \rightarrow \text { Behavioral } \\
\text { Intention }\end{array}$ & .300 & 3.182 & .001 & Significance \\
\hline
\end{tabular}

\section{Hypothesis Testing}

As a result of the bootstrapping of the structural model, as shown in table 5, there is a relationship between the variables built in this research. Perceived Ease of Use has a positive relationship with Attitude Toward Using for students' parents towards online learning applications. However, this relationship does not have a strong level of significance, this is indicated by a $t$-value below 1.96 (level of significance $=5 \%$ ), and $p$ values are above .05 . The results do not support the hypothesis built in this research, namely H1: Perceived Ease of Use has a significant effect on Attitude Toward Using. Therefore, H1 is rejected. 
However, on the other side, the results show that Perceived Ease of Use has a positive and significant relationship with Perceived Usefulness. It can be seen in the $t$-values above 1.96 and p-values below .05, and the positive path coefficient. These results support The hypothesis is built where H2: Perceived Ease of Use has a significant effect on Perceived Usefulness. Based on the results above, $\mathrm{H} 2$ is accepted.

The results also show a positive and significant relationship in Perceived Usefulness to Attitude Toward Using for parents of students at the primary education level in using online learning applications. The results show a positive path coefficient value with a t-value above 1.96. Moreover, with p-values below .05, these results support the hypothesis H3: Perceived Usefulness has a significant effect on Attitude Toward Using. So it can be concluded that $\mathrm{H} 3$ is accepted. Likewise with Perceived Usefulness on Behavioral Intention To Use, which shows positive and significant results with a positive path coefficient value, has a $\mathrm{t}$-value above 1.96 and a p-value below .05 so that the hypothesis that H4: Perceived Usefulness has a significant effect on Behavioral Intention To Use proved / H4 accepted.

Furthermore, the measurement results also show a positive and significant relationship between Attitude Toward Using and Behavioral Intention To Use where the positive path coefficient value has a $t$-value above 1.96 and a $p$-value below .05 , these results support the hypothesis that Attitude Toward Using has an effect. which is significant towards Behavioral Intention to Use, or it is concluded that $\mathrm{H} 5$ is accepted. The overall results of the structural model measurement using PLS-SEM are presented in Figure 3.

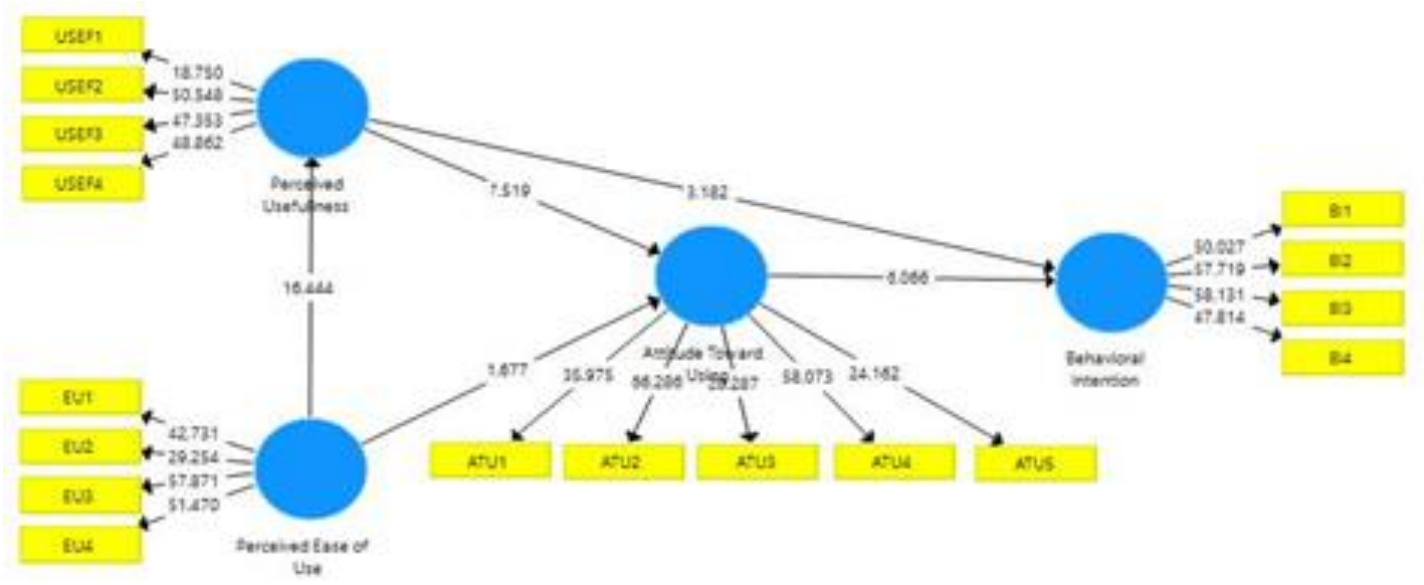

Figure 3. Bootstrapping result of Structural Model in PLS-SEM

\section{Mediation Relations}

In examining the mediation effect of the Attitude Toward Using variable on the Perceived Ease of Use and Perceived Usefulness variables on Behavioral Intention, bootstrapping PLS-SEM is carried out (Preacher \& Hayes, 2008). In PLS-SEM, mediation can occur if the indirect effects on the confidence intervals bias corrected data at a significance level with the lower and upper limits used show the overall positive or negative results. If the value of 0 is outside the lower and upper limits then there is an indirect effect and it shows the mediating effect of a variable (Hayes, 2009). 
Table 6. Mediation results

\begin{tabular}{lcccccc}
\hline \multicolumn{1}{c}{ Relationships } & $\begin{array}{c}\text { Path } \\
\text { Coefficients }\end{array}$ & $t$-Values & $p$-Values & $\mathbf{2 . 5 0 \%}$ & $\mathbf{9 7 . 5 0 \%}$ & Sig. Level \\
\hline $\begin{array}{l}\text { PEU } \rightarrow \text { PU } \rightarrow \\
\text { ATU }\end{array}$ & .497 & 6.199 & .000 & .362 & .677 & Significance \\
\hline $\begin{array}{l}\text { PEU } \rightarrow \text { ATU } \rightarrow \\
\text { B }\end{array}$ & .097 & 1.481 & .139 & -.270 & .223 & $\begin{array}{c}\text { Not } \\
\text { Significance }\end{array}$ \\
\hline $\begin{array}{l}\text { PU } \rightarrow \text { ATU } \rightarrow \\
\text { BI }\end{array}$ & .346 & 5.333 & .000 & .240 & .492 & Significance \\
\hline $\begin{array}{l}\text { PEU } \rightarrow \text { PU } \rightarrow \\
\text { ATU } \rightarrow \text { BI }\end{array}$ & .263 & 4.846 & .000 & .178 & .391 & Significance \\
\hline \begin{tabular}{l} 
PEU $\rightarrow$ PU $\rightarrow$ BI \\
\hline
\end{tabular} & .228 & 3.049 & .002 & .081 & .376 & Significance \\
\hline
\end{tabular}

Table 6 shows the results that Attitude Toward Using does not have a mediating effect for Perceived Ease of Use on Behavioral Intention, even though there is a positive relationship with the path coefficient .497. However, the designation of $\mathrm{t}$-values and $\mathrm{p}$ values are outside the recommended values (t-values <1.96 and $\mathrm{p}$-values $>.05$ ). So no significant relationship is found in these variables. When compared with the lower and upper limits at the level of significance, the value of 0 is between the two limits, which means that is no indirect effect. Nevertheless, on the other side, if Perceived Usefulness becomes the mediating variable, there will be a positive and significant relationship. The mediating effect of Attitude Toward Using occurs in the relationship between Perceived Usefulness and Behavioral Intention. The results show a positive and significant relationship with a path coefficient of .346, t-values $>1.96$, and p-values $<.05$, while indirect effects are shown with a value of 0 , which is outside the upper limit and lower limit of the defined level of significance $(.240-.492)$.

From the research results obtained, the variable that is more important to the Behavioral Intention to Use of students' parents in online learning applications is Perceived Usefulness, compared to Attitude toward Using and Perceived Ease of Use. Perceived Usefulness is the variable with the most significant influence in influencing the acceptance of online learning applications for parents of students using online learning applications. Perceived Usefulness is also the best mediating variable to determine the relationship between Perceived Ease of Use and Behavioral Intention to Use.

Acceptance of the Hypotheses H2, H3, and H4 supports research (Masrom, 2007) as the first TAM research conducted to determine the acceptance of e-learning. However, contrary to the results obtained, the relationship between Attitude Toward Using and Behavioral Intention To Use in this research is significant, whereas in (Masrom, 2007) it is not significant. This difference can be made possible because nowadays the internet usage for daily needs is very high and the level of technology literacy is higher than many years ago so that people are accustomed to using various kinds of applications for their daily needs. This causes the Behavioral Intention To Use for using online learning applications to be higher than during the research period (Masrom, 2007) conducted 13 years ago.

In addition, this research was conducted in a condition where parents did not have any other alternatives to replace online learning applications. Meanwhile in research (Masrom, 2007), it is stated that e-learning is not a substitute for traditional learning models, but rather aims to utilize information technology and the internet to provide a variety of 
communication methods between students and teachers and provide easy access for teaching and learning activities anywhere and anytime, so it can be said that users still have other alternatives for learning besides using the online learning/e-learning application.

With the acceptance of Hypotheses H2, H3, and H4, it shows a significant relationship in the relationship between Perceived Ease of Use and Perceived Usefulness, Perceived Usefulness with Attitude Toward Using and Perceived Usefulness with Behavioral Intention To Use. The significant relationship between Perceived Ease of Use and Perceived Usefulness shows that the ease of using online learning provides benefits for respondents. The significant relationship between Perceived Usefulness and Attitude Toward Using shows that the benefits of online learning applications felt by respondents can increase respondents' confidence in using online learning applications. The significant relationship between Perceived Usefulness and Behavioral Intention to Use shows that the benefits in using online learning applications affect the respondents' intention to continue using online learning applications in the future.

Another difference, H1 in this research is not significant, where in (Masrom, 2007) found that Perceived Ease of Use has a significant effect on Attitude Toward Using. This is possible because the respondent's experience of using various other applications at this time is getting higher, where many of the applications they have experienced are easy and beneficial compared to 13 years ago so that respondents' expectations of an application are higher, respondents prioritize benefits of online learning applications rather than ease of use. This is indicated by the mediating role of the Perceived of Usefulness variable, which makes the relationship between Perceived Ease of Use and Attitude Toward Using more significant.

The results of rejection of Hypothesis $\mathrm{H} 1$ and acceptance of Hypotheses H2, H3, H5 are consistent with research results (Robinson, 2019), regarding research on e-learning acceptance for non-traditional student respondents. The research also resulted in an insignificant relationship between Perceived Ease of Use and Attitude Toward Using. A significant relationship is shown in the relationship between Perceived Ease of Use and Perceived Usefulness, Perceived Usefulness with Attitude Toward Using and Attitude Toward Using with Behavioral Intention To Use. In the acceptance of Hypothesis H5, the significant relationship between Attitude Toward Using and Behavioral Intention To Use shows that a strong belief in using online learning applications affects respondents' intention to continue using online learning applications in the future.

The similarity of this research results with research (Robinson, 2019) is possible because of the same conditions in the respondents. In this research, parents had no other choice but to operate an online learning application so that their children could continue to learn because the learning model transition process was very sudden, as a form of anticipation and control of the Covid-19 pandemic. Besides, the online learning model has never been applied before at the elementary school level. In research (Robinson, 2019) states that most cases, online learning is the only option for non-traditional students to continue their learning because they also must work. The condition of respondents who do not have the opportunity to choose continuing education options other than using online learning applications is the primary influence of the perception that the ease of online learning applications / Perceived Ease of Use does not significantly affect Attitude Toward Using. The Effect of Perceived Ease of Use is not significant for Attitude Toward Using because even though online learning applications are easy or difficult to use, respondents have no other choice because, in the condition of Covid-19 pandemic, face-to-face learning could not 
be conducted. As a result of this, online learning applications will continue to be used. However, based on the overall results, respondents still pay attention to the perceived usefulness for their intentions and attitudes to continue using online learning applications.

The contribution given to the results of this research, from a theoretical perspective, shows that the instruments used in this research are valid and reliable to measure the acceptance of parents of elementary school students to online learning applications. Through the original TAM model without the addition of other variables in the research model, it has been able to prove the purpose of this research in analyzing the extent to which parents of elementary school students accept online learning application technology as a learning method currently applied. In the context of using the original TAM in this research, all variables with their indicators can provide an overview of the level of validity and reliability following the minimum required values.

The acceptance of parents of elementary school students towards online learning applications with TAM in this research shows the relationship between variables of concern to parents of elementary school students towards online learning applications. the minimum required composite reliability $(>.70)$, which all four values are $>.9$. In addition, this instrument is valid to used as a measuring tool because the outer loading of all indicators is $>.70$ and the AVE of all constructs fulfills the required value $(>.05)$, which all four values are $>.75$. This research model results are consistent and in accordance with TAM, because the Path Coefficient values on the Structural Model Result listed in the Table are all positive. The TAM model in this research also clearly show that the Perceived Ease of Use variable as one of the basic variables in TAM does not significantly affect on Attitude Toward Using, in contrast to other variables that show significance and affect the acceptance of parents. Primary Schools on online learning applications and their perspectives for the future.

In this research, it was found that the acceptance of parents of elementary school students for online learning applications to support SFH activities during the pandemic did not depend on its ease of use, which indicating the level of Perceived Ease of Use. Those can be happened since the respondents have also considered the benefits (Perceived Usefulness) of the online learning application. It can be seen that, in addition to mandatory basic education for students, the behavior and intention of parents to support teaching and learning activities for their children can is quite good in the midst of a pandemic.

It is our responsibility together for the continuity of the education of a generation. The government could provide policies, regulations, supporting infrastructure, adequate facilities and infrastructure for the smooth running of this online learning activity. For example, a reliable internet network in all regions, free or cheap mobile data for internet for teachers and parents of students, or even collaborating with application developers to create teaching and learning applications that are cheap, standardized, quality and integrated so that all students everywhere will receive the same material, and there is no gap between students in big cities and rural areas. The Ministry of Education and Culture and the school should work together to formulate an online learning curriculum that is suitable for its students. Meanwhile, parents accompany their sons and daughters to help them learning and make sure they can keep up with school.

As it is known that distance teaching and learning activities for elementary school students have never been done before, it is necessary to adjust the learning model from offline to online. For example, the adjustment for duration of the activity (1 hour of lesson does not exceed 45 minutes) and the proportion adjustment between teaching activity and assignments/homework. In addition, the pandemic situation greatly reduce outdoor 
activities, the stress levels of parents and students themselves also need to be concerned. Variations in learning methods are needed so that students do not become bored with distance teaching and learning activities. For example, teachers can give interactive quizzes using applications such as Kahoot, Quizzes, or Mentimeter to provide interesting and informative practice questions, prioritize interactive 2-way discussions, and provide interesting and fun educational videos.

In providing interesting and interactive subject matter, it requires training/material for online teaching methods for the teaching staff. Given that elementary school age students are still very active and easily bored if they just listen to the material for a long time. Online learning is indeed a great way to help learning process and activity in the midst of current conditions, but it is not without obstacles, with good cooperation between all parties, the obstacles can be reduced and more solutions will be found for continuous improvement of the online learning process.

\section{Conclusion}

This research provides meaningful results to see the extent to which parents accept online learning applications and also continuity of online learning applications in the future, but researchers are aware of some limitations in conducting research. The limitation of this research is that the research coverage area is still limited (Jabodetabek area) so that the results of this research cannot represent the condition of all parents of elementary school students in Indonesia. This research also has not measured other factors that cause limitations in conducting School From Home, where research is considered to be conducted in ideal conditions so that the respondent's response to the acceptance of online learning applications is not influenced by other variables, such as the limitations of the internet network for School From Home activities, the availability of costs to provide computer, smartphones or internet data packages for online learning, and availability of time for parents to accompany their sons or daughters in operating an online learning application. In addition, limitations from the researchers' side include limited time, cost, and difficulties in data collection (due to the researchers' domicile in the Jabodetabek area), if the research coverage area is extended to other areas outside Jabodetabek.

Furthermore, this research has not fully extended to measure other TAM variables, because reffering to the original TAM (Davis et al., 1989), there is one variable that has not been measured, namely Actual System Use. This variable measures the actual use of online learning applications, respondents who believe and confident that online learning applications can provide benefits and convenience can be seen from the frequency of actual use of online learning applications. Therefore, it is hoped that a comprehensive TAM research involving the variable that has not been measured in this research can provide a better result and more insights of this research.

Because this research is the first research conducted using TAM to determine the acceptance of parents of elementary school students for online learning applications, for future research, researchers hope that further researches can be carried out on this subject. For example, by adding other variables that affect the acceptance of online learning applications for parents as companions. Then, it is hoped that future researches can be carried out with wider coverage areas with a broader scope of researches that will provide 
more insights into the acceptance of parents of elementary school students in Indonesia on the use of online learning application.

\section{References}

Abbas, H. A., \& Hamdy, H. I. (2015). Determinants of continuance intention factor in Kuwait communication market: Case study of Zain-Kuwait. Computers in Human Behavior. https://doi.org/10.1016/j.chb.2015.03.035

Al-Rahmi, W. M., Alias, N., Othman, M. S., Alzahrani, A. I., Alfarraj, O., Saged, A. A., \& Rahman, N. S. A. (2018). Use of E-Learning by University Students in Malaysian Higher Educational Institutions: A Case in Universiti Teknologi Malaysia. IEEE Access. https:// doi.org/10.1109/ACCESS.2018.2802325

Al-Smadi, M. O. (2012). Factors Affecting Adoption of Electronic Banking : An Analysis of the Perspectives of Banks ' Customers. International Journal of Business and Social Science.

Barbosa, T. J. G., \& Barbosa, M. J. o. (2019). Zoom: An Innovative Solution for the Live-online Virtual Classroom. HETS Online Journal.

Candarli, D., \& Yuksel, H. G. (2012). Students' Perceptions of Video-Conferencing in the Classrooms in Higher Education. Procedia - Social and Behavioral Sciences. https://doi.org/10.1016/j.sbspro.2012.06.663

Chinn, W. W. (1998). The Partial Least Squares Approach to Structural Equation Modelling. Modern Methods for Business Research.

Cronbach, L. J. (1951). Coefficient alpha and the internal structure of tests. Psychometrika. https://doi.org/10.1007/BF02310555

Davis, F. D., Bagozzi, R. P., \& Warshaw, P. R. (1989). User Acceptance of Computer Technology: A Comparison of Two Theoretical Models. Management Science. https://doi.org/10.1287/mnsc.35.8.982

Farahat, T. (2012). Applying the Technology Acceptance Model to Online Learning in the Egyptian Universities. Procedia - Social and Behavioral Sciences. https://doi.org/10.1016/j.sbspro.2012.11.012

Fishbein, M., \& Azjen, I. (1975). Belief, Attitude, Intention, and Behavior: An Introduction to Theory and Research. Reading, MA: Addison-Wesley. Contemporary Sociology.

Fornell, C., \& Larcker, D. F. (1981). Structural Equation Models with Unobservable Variables and Measurement Error: Algebra and Statistics. Journal of Marketing Research. https://doi.org/10.1177/002224378101800313

Hair, Hult, Ringle, \& S. (2013). A Primer on Partial Least Squares Structural Equation Modeling (PLS-SEM). Thousand Oaks. Sage. 
Hair, J. F., Hult, G. T. M., Ringle, C. M., \& Sarstedt, M. (2013). A Primer on Partial Least Squares Structural Equation Modeling (PLS-SEM). Thousand Oaks. Sage.

Hair, J. F., Hult, G. T. M., Ringle, C. M., \& Sarstedt, M. (2017). A Primer on Partial Least Squares Structural Equation Modeling (PLS-SEM). Second Edition. In California: Sage.

Hair, Joseph F, Black, W. C., Babin, B. J., \& Anderson, R. E. (2019). Multivariate Data Analysis. In TORUS 1 - Toward an Open Resource Using Services.

Handoko, B. L. (2019). Application of UTAUT theory in higher education online learning. ACM International Conference Proceeding Series. https:// doi.org/10.1145/3345035.3345047

Hayes, A. F. (2009). Beyond Baron and Kenny: Statistical mediation analysis in the new millennium. Communication Monographs. https://doi.org/10.1080/03637750903310360

Hollingworth, S., Mansaray, A., Allen, K., \& Rose, A. (2011). Parents' perspectives on technology and children's learning in the home: Social class and the role of the habitus. Journal of Computer Assisted Learning. https://doi.org/10.1111/j.13652729.2011.00431.x

Hussein, Z. (2017). Leading to Intention: The Role of Attitude in Relation to Technology Acceptance Model in E-Learning. Procedia Computer Science. https://doi.org/10.1016/j.procs.2017.01.196

Ibrahim, R., Leng, N. S., Yusoff, R. C. M., Samy, G. N., Masrom, S., \& Rizman, Z. I. (2018). Elearning acceptance based on technology acceptance model (TAM). Journal of Fundamental and Applied Sciences. https://doi.org/10.4314/jfas.v9i4s.50

Kapoor, K., Dwivedi, Y., Piercy, N. C., Lal, B., \& Weerakkody, V. (2014). RFID integrated systems in libraries: Extending TAM model for empirically examining the use. Journal of Enterprise Information Management. https:/ / doi.org/10.1108/JEIM-10-20130079

Lanlan, Z., Ahmi, A., \& Popoola, O. M. J. (2019). Perceived ease of use, perceived usefulness and the usage of computerized accounting systems: A performance of micro and small enterprises (mses) in china. International Journal of Recent Technology and Engineering. https:// doi.org/10.35940/ijrte.B1056.0782S219

Li, H., \& Liu, Y. (2014). Understanding post-adoption behaviors of e-service users in the context of online travel services. Information and Management. https://doi.org/10.1016/j.im.2014.07.004

Loanata, T., \& Tileng, K. G. (2016). Pengaruh Trust dan Perceived Risk pada Intention To Use Menggunakan Technology Acceptance Model (Studi Kasus Pada Situs E- 
Commerce Traveloka). Juisi.

Masrom, M. (2007). Technology acceptance model and E-learning. 12th International Conference on Education.

Ozturk, A. B., Bilgihan, A., Nusair, K., \& Okumus, F. (2016). What keeps the mobile hotel booking users loyal? Investigating the roles of self-efficacy, compatibility, perceived ease of use, and perceived convenience. International Journal of Information Management. https:/ / doi.org/10.1016/j.ijinfomgt.2016.04.005

Park, N., Rhoads, M., Hou, J., \& Lee, K. M. (2014). Understanding the acceptance of teleconferencing systems among employees: An extension of the technology acceptance model. Computers in Human Behavior. https://doi.org/10.1016/j.chb.2014.05.048

Powell, L., \& Wimmer, H. (2017). Parental Perceptions and Recommendations of Computing Majors: A Technology Acceptance Model Approach. Information Systems Education Journal.

Preacher, K. J., \& Hayes, A. F. (2008). Asymptotic and resampling strategies for assessing and comparing indirect effects in multiple mediator models. Behavior Research Methods. https:/ / doi.org/10.3758/BRM.40.3.879

Robinson, T. (2019). Using the Technology Acceptance Model to Examine Technology Acceptance of Online Learning Technologies by Non-Traditional Students. IManager's Journal of Educational Technology. https://doi.org/10.26634/jet.16.1.15826

Rodrigues Pinho, J. C. M., \& Soares, A. M. (2011). Examining the technology acceptance model in the adoption of social networks. Journal of Research in Interactive Marketing. https://doi.org/10.1108/17505931111187767

Salloum, S. A., Qasim Mohammad Alhamad, A., Al-Emran, M., Abdel Monem, A., \& Shaalan, K. (2019). Exploring students' acceptance of e-learning through the development of a comprehensive technology acceptance model. IEEE Access. https://doi.org/10.1109/ACCESS.2019.2939467

Santoso, B. (2004). Pengaruh Perceived Usefulness, Perceived Ease Of Use, dan Perceived Enjoyment terhadap Penerimaan Teknologi Informasi (Studi Empiris di Kabupaten Sragen). Studi, Jurnal Indonesia, Akuntansi.

Sekaran, U., \& Bougie, R. (2016). Reserach Methods for Bussiness A Skill-Bulding Approach. Printer Trento Srl.

Suh, B., \& Han, I. (2002). Effect of trust on customer acceptance of Internet banking. Electronic Commerce Research and Applications. https:/ / doi.org/10.1016/S1567-4223(02)00017-0

Sun, L., Tang, Y., \& Zuo, W. (2020). Coronavirus pushes education online. In Nature 
Materials. https://doi.org/10.1038/s41563-020-0678-8

Tan, G. W. H., Ooi, K. B., Sim, J. J., \& Phusavat, K. (2012). Determinants of mobile learning adoption: An empirical analysis. In Journal of Computer Information Systems. https://doi.org/10.1080/08874417.2012.11645561

Tarhini, A., Hone, K., \& Liu, X. (2013). User acceptance towards web-based learning systems: Investigating the role of social, organizational and individual factors in european higher education. Procedia Computer Science. https://doi.org/10.1016/j.procs.2013.05.026

Vijayasarathy, L. R. (2004). Predicting consumer intentions to use on-line shopping: The case for an augmented technology acceptance model. Information and Management. https://doi.org/10.1016/j.im.2003.08.011

Wang B. \& Ha-Brookshire J.E. (2019). Perceived Cost of New Technology Adoption: Scale Development in the Context of Chinese Textile and Apparel Firm Managers. International Textile and Apparel Association Annual Conference Proceedings. https://doi.org/doi.org/10.31274/itaa.8423

Weng, F., Yang, R.-J., Ho, H.-J., \& Su, H.-M. (2018). A TAM-Based Study of the Attitude towards Use Intention of Multimedia among School Teachers. Applied System Innovation. https:// doi.org/10.3390/asi1030036 